\title{
Accessibility for Persons with Disabilities in Trans Metro Bandung Services
}

\author{
Jeremia Gom Gom Parulian $^{1 *}$; Budiman Rusli² ; Elisa Susanti ${ }^{3}$ \\ ${ }^{1,2,3}$ Public Administration Study Program, Postgraduate Program of the Faculty Social and Political Sciences, \\ Padjadjaran University, Bandung, Indonesia.
}

\begin{abstract}
Public services, especially public transportation services for persons with disabilities, have not been well organized and have not been based on equality even though various laws and regulations have regulated them. One form of implementing equality for persons with disabilities is the provision of accessibility facilities to support and assist them in using a service. Based on the characteristics of the research object, the method used is a qualitative method with a descriptive approach. The technique of collecting data is done by in-depth interviews, observations, and library studies. This article is intended to provide an overview regarding the provision of accessibility facilities for persons with disabilities in the Trans Metro Bandung services and also provides an overview regarding the implementation of Trans Metro Bandung services for persons with disabilities in the city of Bandung.
\end{abstract}

Keywords: Accessibility, Persons with Disabilities, Public Transportation Services, Trans Metro Bandung

\section{Research Background}

Respect and fulfillment the rights of persons with disabilities right now is a global issue. After the issuance of United Nations Resolution No.61 of 2006 concerning Convention on the Right of Persons with Disabilities (CRPD), there are paradigm changes and approaches to persons with disabilities. Disability is no longer seen as a flaw or weaknesses in a person, but is seen as a diversity that is owned by someone.

Persons with Disabilities according to Undang - Undang Republik Indonesia No.8 2016 are those who experience physical, intellectual, mental, and / or sensory limitations for a long period of time who interact with the environment can experience obstacles and difficulties to participate fully and effectively with citizens based on similar rights.

Corresponding author: Jeremia Gom Gom Parulian jeremia19.simanjuntak@gmail.com

Published online at http://IJDS.ub.ac.id/2019-1

Copyright (C) 2019PSLD UB Publishing. All Rights Reserved
Persons with disabilities made up of persons with physical disabilities, persons with intellectual disabilities, people with mental disabilities and persons with sensory disabilities. At present, disability is more viewed from the social side, namely as a human diversity. The obstacles faced by persons with disabilities are the implications of inadequate environmental conditions and do not accommodate the interests of persons with disabilities.

Persons with disabilities, with all the limitations they face, they are also Indonesian citizens who are guaranteed roles, rights and obligations in the 1945 constitution. For this reason the government is obliged to guarantee that the rights of persons with disabilities fulfilled as the government guarantees and fulfills the rights of people who do not have physical abnormalities or "normal" communities.

Public service is the right of all citizens, including persons with disabilities, the government as the organizer of public services is obliged to ensure that the rights of all citizens without exception are guaranteed in accessing public services. The reality in the field at this time generally indicates the existence of 
"disharmony" between public services and persons with disabilities. The rights of persons with disabilities in public services are neglected and not accommodated. Persons with disabilities tend to lose their rights to get good public services.

Regarding public services, one of the public services needed by the community, including persons with disabilities, is public transportation services. Public transportation services are a very important service for people of all ages and backgrounds to live a life. Transportation plays an important role in many aspects of daily life including access to work, education, health centers, shopping centers, social events and tourism. Simply put, transportation is a necessity for full participation in a community ( Bezyak., Et al.: 2017).

In the context of persons with disabilities, transportation is also important for their lives. Accessible transportation allows persons with disabilities to live independently and have transportation services; notified of services; know how to use it; can use it; and have the means to pay for it (Wilson: 2003). Affordable and accessible transportation enables persons with disabilities to access important opportunities in education, employment, health care, housing, and in community life.

Various previous studies ( Ahmad: 2015; Bezyak., Et al: 2017) has shown that the importance of public transportation for persons with disabilities. Persons with disabilities requires public transportation and requires accessibility facilities to be able to access it. Previous research has shown that public transportation services for persons with disabilities are still unable to fully provide accessibility facilities and still provide various obstacles for persons with disabilities in accessing public transportation services, the limitations of accessibility facilities also cause limitations in disabled mobility and independence in their social life.

The city of Bandung itself is one of the pioneers in making Regional Regulations for persons with disabilities. Regional Regulation or Peraturan Daerah (Perda) of Bandung City Number 26 of 2009 concerning Equality and Empowerment of Persons with Disabilities is the first Regional Regulation in Indonesia that regulates the rights and obligations of persons with disabilities. Meanwhile, the Regional Regulation or Peraturan Daerah (Perda) of
Bandung City Number 16 of 2011 concerning Public Services has also regulated the right of public services for persons with disabilities and regulates the implementation of inclusive public services.

One of the public transport service in the city of Bandung is Trans Metro Bandung (TMB). Trans Metro Bandung is an urban mass transportation that began operating in 2004 which was formed to improve the urban public transport system through management and the provision of mass transportation facilities in accordance with the wishes of the community and to improve public services, especially in the field of land transportation in the city of Bandung.

Currently Trans Metro Bandung operates and serves the community with 4 routes, namely:

Corridor 1: Cibereum - Cibiru .

Corridor 2: Cicaheum - Cibereum .

Corridor 3: Cicaheum - Sarijadi .

Corridor 4: Leuwi Panjang -Antapani.

The operation of Trans Metro Bandung itself is aimed at reforming the urban public transport system through management and the provision of mass transportation facilities in accordance with the wishes of the community, namely safe, comfortable, easy, on time and cheap; serving urban passengers (Central Business District (CBD) city of Bandung) and outside passengers of the City of Bandung (Outer Cordon/ Bandung Raya); and improvement of urban public transport service systems.

With regard to persons with disabilities, there is a tendency that the persons with disabilities will be forgotten by the fact that public transportation services themselves are services that are also a necessity for persons with disabilities to support their mobility, which tends to be forgotten, that persons with disabilities also have the right to get transportation services public just like any other community. Persons with disabilities need public transportation services just like other communities, except that in the process, people with disabilities need a variety of special needs to overcome the constraints of their physical limitations, including special needs such as the availability of accessibility facilities for persons with disabilities in the provision of services. .

The description of the not yet optimal public transportation services for persons with 
disabilities in the city of Bandung, especially in TMB services can be seen from the emergence of petitions made by persons with disabilities on TMB services on change.org, the petition was made in 2015 and the petition was signed by 3,339 people and in essence, the petition

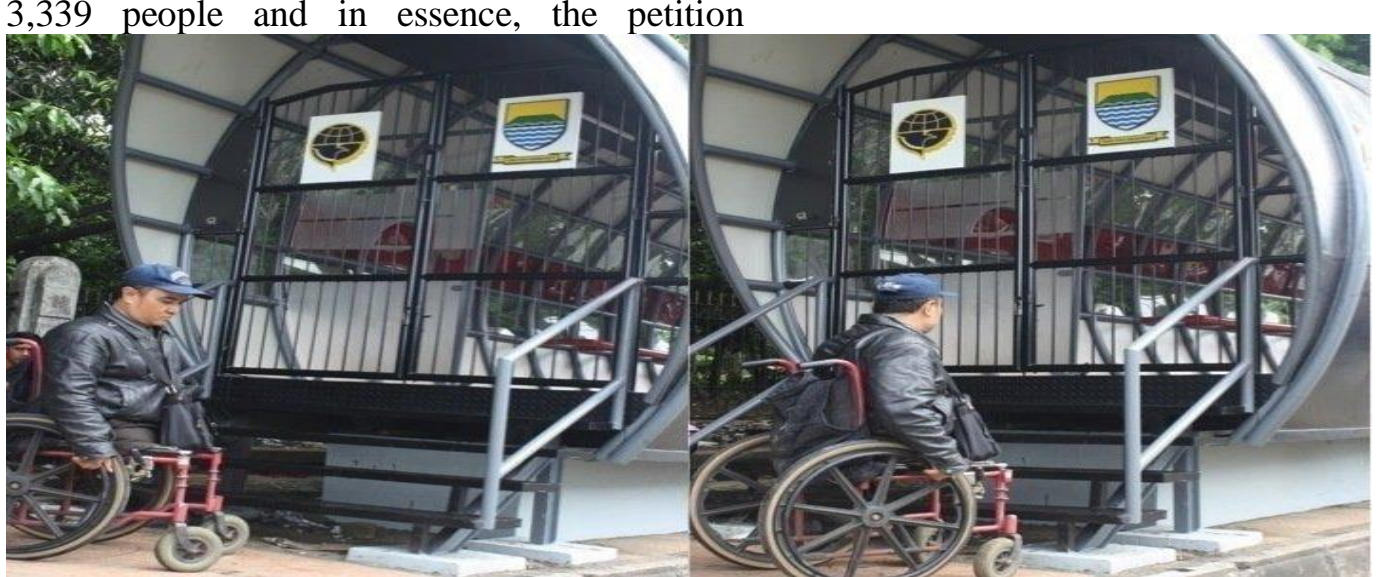

Figure 1. Trans Metro Bandung Shelter Source: change.org (2015)

This group of persons with disabilities, due to their physical limitations, certainly needs different needs from other community groups. Nevertheless, they have rights and need equal access to public services. In general, the current public services are still same and only oriented to the main group, namely the "normal" community and this is also seen in the implementation of public services in the city of Bandung, especially in the service of Trans Metro Bandung. The government's attention to the implementation of good public services for persons with disabilities is still little.

\section{Methods}

The method used in writing this article is a qualitative method with a descriptive approach. According to Creswell (2010: 5) that qualitative research is methods for exploring and understanding meaning that by a number of individuals or groups of people are ascribed to social / humanitarian problems.

In writing this article the data collected is primary and secondary data. In collecting information and data needed, then using three data collection techniques, which consist of observation, in-depth interviews and library studies. The selection of informants in writing this article is based on research subjects who master the problem, have data, and are willing to provide data. The informants in this demanded that TMB services be carried out equally and pay attention to persons with disability needs, one of which was through the provision of accessibility facilities within the TMB shelter.

study were informants from the UPT. Angkutan Dinas Perhubungan Kota Bandung as the managing body of Trans Metro Bandung and the disabled community consisting of physical disabilities, visual disabilities and hearing disabilities.

The data analysis technique used is the data analysis technique model Miles \& Huberman (1992), which consists of:

Data Reduction (Data Reduction)

Data Display (Data Presentation)

Conclusion Drawing /

Verfication (Withdrawal Conclusion)

\section{Results}

\section{Accessibility Policy for Persons With Disabilities}

Judging from the existing policies, relating to the provision of accessibility facilities for persons with disabilities themselves, it has been regulated in the Regional Regulation or Peraturan Daerah (Perda) of Bandung City Number 26 of 2009 concerning Equality and Empowerment of Persons with Disabilities and stated in articles 29-36. These articles have been regulated that the regional government of Bandung must provide accessibility facilities for persons with disabilities, ranging from accessibility to public buildings, accessibility on public roads, accessibility to public parks and cemeteries, accessibility to public transport and accessibility to religious facilities.

Meanwhile, related to accessibility for persons with disabilities in public transportation services has also been regulated in the Minister 
of Transportation Regulation of the Republic of Indonesia Number 98 of 2017 concerning Provision of Accessibility in Public Transportation Services for Service Users with Special Needs, namely in articles 3 and 4. Inside these articles have been stipulated that the providers of transportation services are required to provide accessibility facilities in transportation services for disabled persons with disabilities. If viewed from the level of existing policies, then related to accessibility for persons with disabilities in the implementation of public transportation services has been clearly regulated, both at the regional and at the central level, meaning that there has been a strong foundation in providing accessibility for persons with disabilities in in public transportation services that require every provider of public transportation services to provide accessibility for persons with disabilities.

\section{Accessibility for Persons with Disabilities in Trans Metro Bandung Services}

In the implementation of Trans Metro Bandung (TMB) services, the facilities and accessibility currently available in supporting the implementation of TMB services for the community are buses and shelters. The TMB bus itself consists of large-sized buses and mediumsized buses and is designed in light blue and dark blue with green and yellow patterns. The buses currently operating are 29 TMB buses. Details of the number of TMB buses in operation are explained in the following table 1 .

Table 1. Trans Metro Bandung Bus

\begin{tabular}{|c|c|c|}
\hline No. & Corridor & Bus Operates \\
\hline 1. & Corridor 1 & 8 \\
\hline 2. & Corridor 2 & 8 \\
\hline 3. & Corridor 3 & 5 \\
\hline 4. & Corridor 4 & 8 \\
\hline
\end{tabular}

Source: UPT. Angkutan Dinas Perhubungan Kota Bandung (2017)

The next supporting facility in the TMB service is the TMB shelter. Shelter is a place for passengers to rise and fall as well as a place to wait for TMB bus arrival time. The shelter itself is located in strategic locations, close to the center of activities with high intensity. TMB shelters that have been built at this time amount to 71 shelters and are divided into 4 corridors. Details of the TMB shelter in the 4 corridors are explained in the following table.

Table 2. Trans Metro Bandung Shelter

\begin{tabular}{|c|c|c|}
\hline No. & Corridor & Shelter \\
\hline 1. & Corridor 1 & 16 \\
\hline 2. & Corridor 2 & 28 \\
\hline 3. & Corridor 3 & 19 \\
\hline 4. & Corridor 4 & 8 \\
\hline
\end{tabular}

Source: UPT. Angkutan Dinas Perhubungan Kota Bandung (2017)

Related to TMB services for persons with disabilities, facilities and those that support comfort and provide accessibility for disabled people in using TMB buses at this time based on the findings of researchers have not been fully fulfilled. The existence of buses and shelters that exist today cannot yet be fully accessed by people with disabilities. Accessibility for people with disabilities is an important thing to be able to help them engage in activities and use public services just like other communities. The unavailability of accessibility for persons with disabilities can lead to negative perceptions and make it difficult for disabled people to use public services, especially TMB services.

Transportation is important for all levels of society, including persons with disabilities, the fulfillment of accessibility facilities is important to create a good and accessible transportation system for persons with disabilities. Because what is seen at this time is that the fulfillment of TMB service support facilities is still oriented towards non-disabled people, and seems to forget about the persons with disabilities community which causes defile people to access TMB services.

In the current TMB service, access for persons with disabilities is still very minimal and not fulfilled. TMB services still cannot provide comfort for persons with disabilities because of the lack of accessibility facilities for TMB services for persons with disabilities. Accessibility facilities for TMB services for disabled people are still lacking in both physical accessibility and information accessibility. It can be seen from the shelter TMB are difficult to use by wheelchair users due to the absence of wheelchair ramps and there is also a shelter that has had wheelchair ramps but the path is not flat and provide difficulties for wheelchair users to access them. 


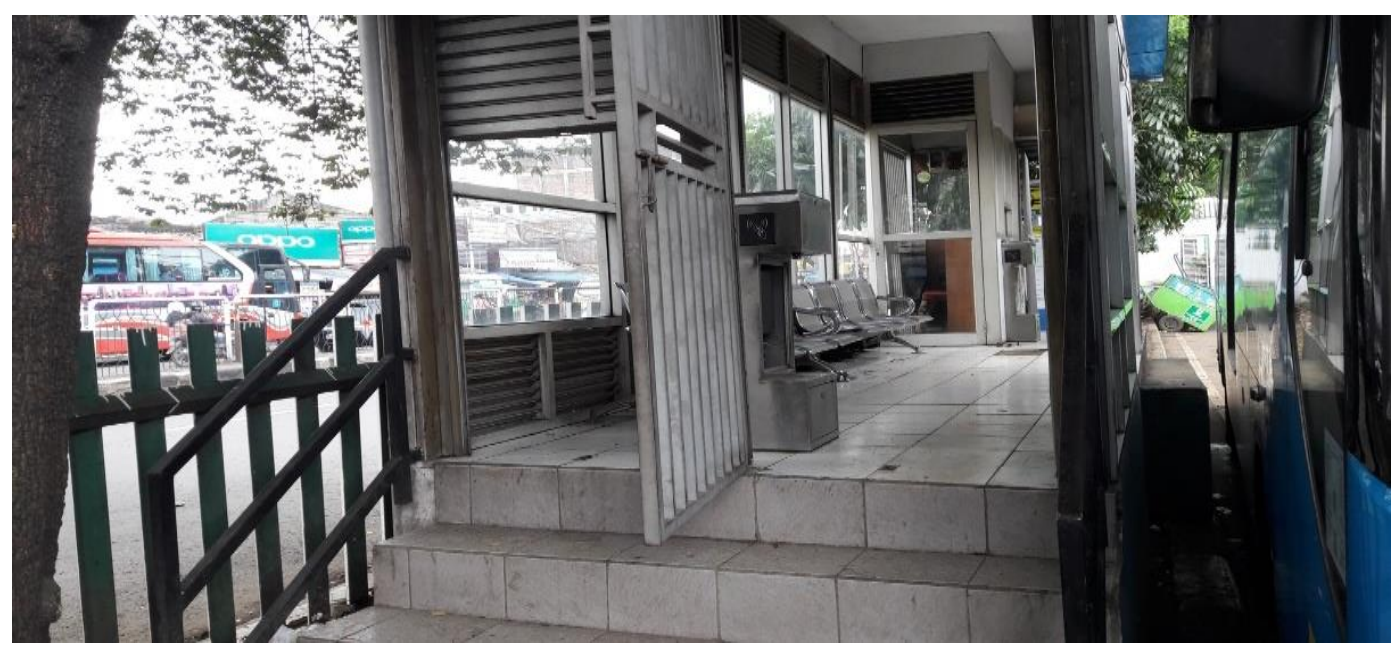

Figure 2. Trans Metro Bandung Shelter in Cicaheum Terminal Bandung Source: Research Documentation (2018)

Description: TMB Shelter in Cicaheum Terminal does not have a wheelchair lane for wheelchair users. In contrast to the above

mentioned shelter, other existing shelters have been equipped with wheelchair ramps access for the disabled, but the wheelchair ramps are impressed steep and dangerous for disabled wheelchair users when using it.

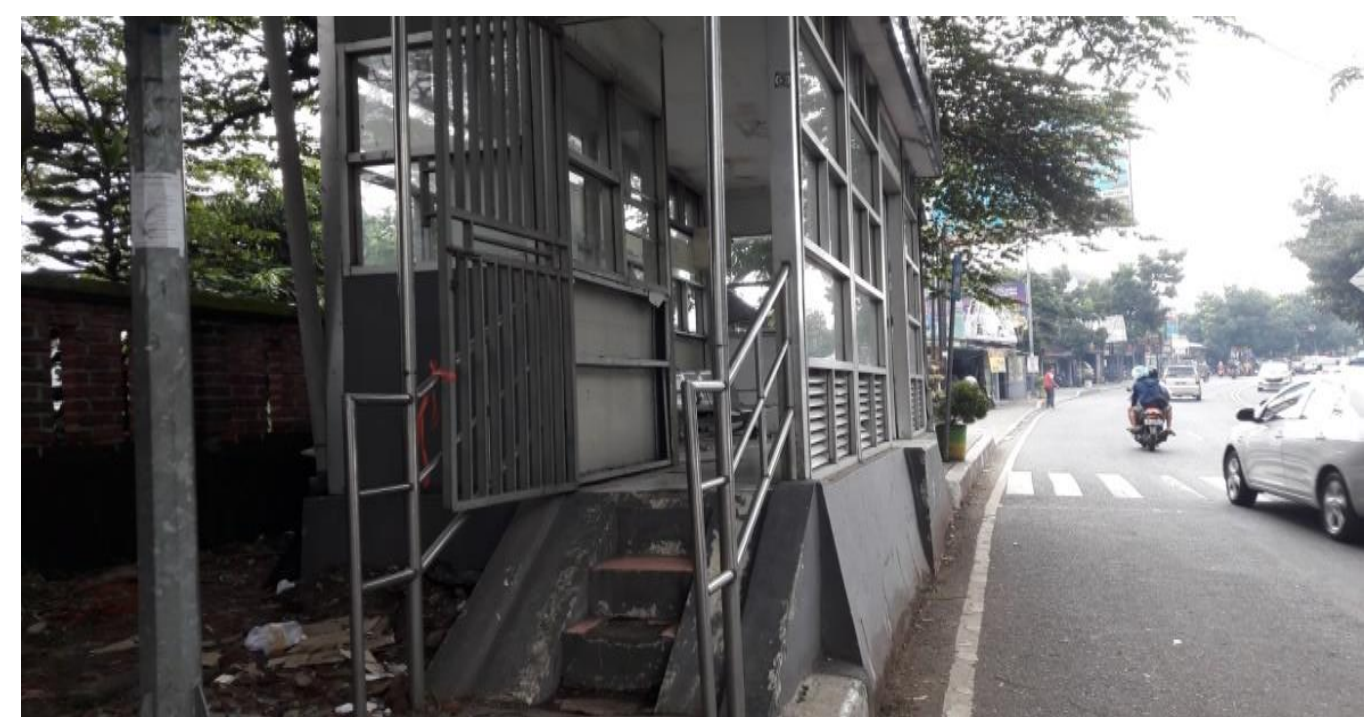

Figure 3. Trans Metro Bandung Shelter in Jln. Surapati Bandung Source: Research Documentation (2018)

Description: TMB Shelter Jl. Surapati have wheelchair ramps but very steep and difficult to use for wheelchair users. In addition to the absence of lanes for wheelchair users, information instructions that are accessible to

persons with disabilities are also not found in the TMB shelter. Information that is accessible to the persons with visual disabilities itself is in the form of information with braille letters that can be read by blind disabilities and information in the form of audio sound that can be heard by persons with visual disabilities. 


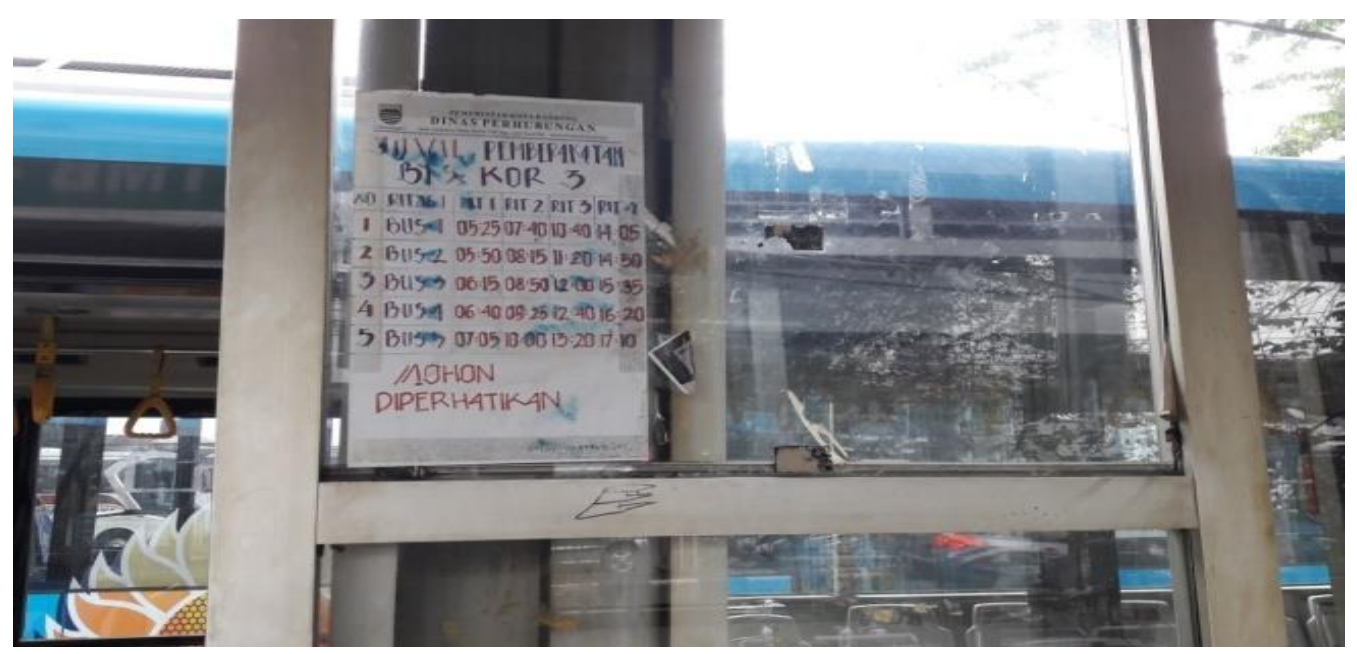

Figure 4. Information on the Trans Metro Bandung Shelter in Cicaheum Terminal Bandung. Source: Research Documentation (2018)

Description: Information on the TMB shelter in Terminal Cicaheum that cannot be accessed by person with visual disabilities. There is also information on the TMB (Signage) route located at TMB shelter, but the signage can only be accessed by non-disabled people and cannot be accessed by persons with disabilities, especially those with disabilities, who only receive information in the form of braille and in the form of audio sound as described previously.

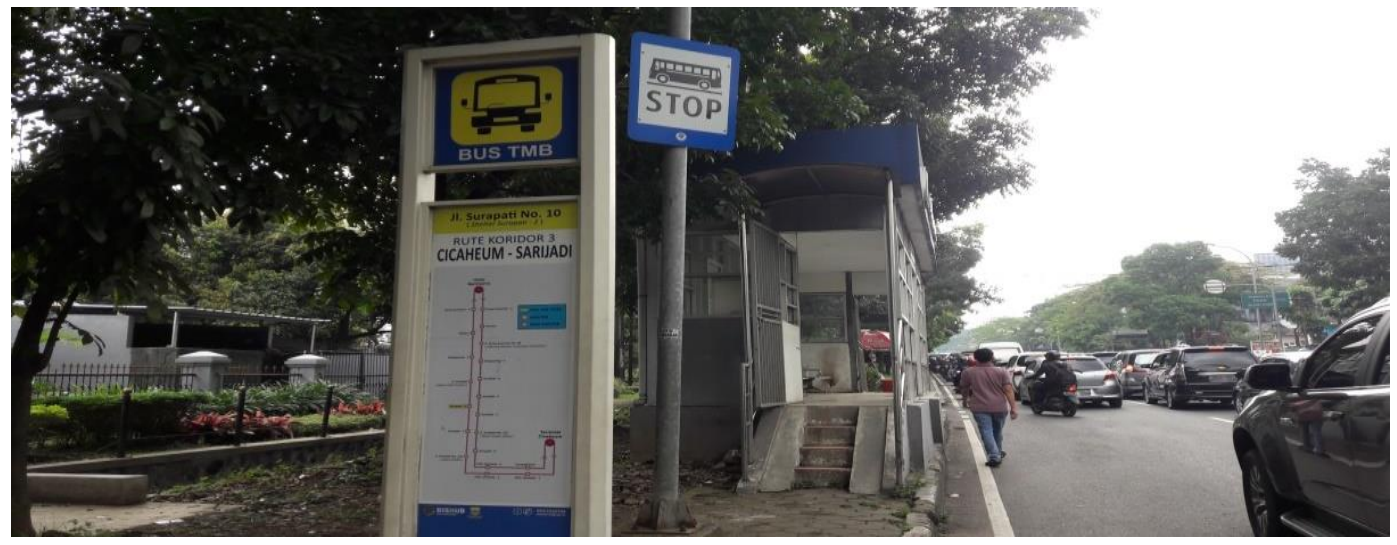

Figure 5. Information on Route at Trans Metro Bandung Shelter in Jln. Surapati Bandung Source: Research Documentation (2018)

Description: Route information (signage) at TMB shelter Jl. Surapati which cannot be accessed by persons with visual disabilities. Meanwhile, based on information obtained from persons with disabilities. Each person's disabilities requires different accessibility. Accessibility requirements for persons with disabilities are outlined in the following table.

The availability of accessibility for persons with disabilities is important because it is to eliminate the obstacles experienced by persons with disabilities in the use of public transportation services, especially TMB services. At present not all TMB shelters are equipped with accessibility for persons with disabilities even though there have been some that have been repaired and added accessibility for persons with disabilities, namely in the form of adding ramps or wheelchair lanes for wheelchair users. The absence of accessibility facilities for persons with disabilities has an impact on the obstacles for disabled people to access TMB services, so the existence of accessibility facilities is very important and must be fulfilled so that persons with disabilities can access TMB services without obstacles and disruptions.

Based on information obtained from persons with disabilities, the absence of accessibility facilities for persons with 
disabilities in TMB services is a major obstacle for disabled people in using TMB bus services, because accessibility facilities play a large role in increasing access to disability in using TMB and minimizing services. barriers encountered by persons with disabilities in using TMB bus services. From the descriptions that have been described previously, it can be said that in the TMB service, persons with disabilities still do not have the required accessibility facilities. Persons with disabilities also still have difficulties in accessing TMB services because accessibility facilities are not fully available in TMB services for persons with disabilities.

Table 3. Accessibility for person with disabilities

\begin{tabular}{|c|l|l|}
\hline No. & $\begin{array}{c}\text { Disabled } \\
\text { type }\end{array}$ & Required Accessibility \\
\hline 1 & $\begin{array}{l}\text { Persons } \\
\text { with visual } \\
\text { disabilities }\end{array}$ & $\begin{array}{l}\text { Information in Braille / } \\
\text { Audio format. } \\
\text { Signs go to the seat on the } \\
\text { bus. } \\
\text { Easy-to-reach handles } \\
\text { for going up and down. }\end{array}$ \\
\hline 2 & $\begin{array}{l}\text { Persons } \\
\text { with } \\
\text { physical } \\
\text { disabilities }\end{array}$ & $\begin{array}{l}\text { - } \\
\text { Ramp (Wheel Chair). } \\
\text { Wheelchair strap on the } \\
\text { bus. }\end{array}$ \\
\hline 3 & $\begin{array}{l}\text { Persons } \\
\text { with } \\
\text { hearing } \\
\text { disabilities }\end{array}$ & $\begin{array}{l}\text { Signs for specific } \\
\text { instructions for hearing } \\
\text { impaired persons. }\end{array}$ \\
& $\begin{array}{l}\text { Visual warning signs in } \\
\text { the form of images or } \\
\text { text. }\end{array}$ \\
\hline
\end{tabular}

These things happened because the implementation of TMB services was not guided by the Bandung City Regulation Number 16 of 2011 concerning Public Services, Bandung City Regulation Number 26 of 2009 concerning Equality and Empowerment of Persons with Disabilities and Transportation Minister Regulation of the Republic of Indonesia Number 98 of 2017 concerning Provision of Accessibility in Public Transportation Services for Service Users with Special Needs that have regulated services for persons with disabilities and regulate the provision of accessibility facilities for disabled people in a public service in general and public transportation services.

\section{Accessibility for Persons With Disabilities As a Form Of Equality In Public Service}

The realization of a fair and equal service is a service that can be enjoyed by every community regardless of the differences that exist in society. In the context of persons with disabilities, fair and equal services are services that can be accessed by persons with disabilities, namely by providing accessibility for persons with disabilities in the implementation of public services.

The implementation of public services according to Denhardt \& Denhardt (2007) must be carried out fairly and equally. Denhardt \& Denhardt argues that the service user community on the other hand is a citizen attached to rights and obligations, these rights must be guaranteed and fulfilled by the government, and public service is also one of the processes by which society gets its rights in terms of service, and the government as the executor and service provider must fulfill it.

The current tendency is that disabled persons are often marginalized and considered "non-existent" in the implementation of a public service, every type of service that exists tends to be designed and carried out with a non-disabled community approach, namely a situation where a service is designed and held as a service it will only be used or accepted by non-disabled persons. The current trend also shows that persons with disabilities only need social services such as rehabilitation, social assistance and other social services. In fact, if you look deeper, persons with disabilities is not just about social services, but also need public services the others as non-disabled persons.

Persons with disabilities as part of "citizens" of course every need for services must be fulfilled by service providers, in the context of TMB services for disabled persons, it has become a necessity that disabled persons needs for accessibility facilities in TMB services are met by service providers to be able to provide comfort for them in the TMB service. Realizing justice, equality, equality of rights and opportunities for persons with disabilities is indeed a challenge for the government today, especially in the current era where persons with disabilities have voiced their demands for equal treatment in all areas of life. At present, discriminatory public service practices cannot be justified, so the government has a great duty and responsibility to ensure fair and equal public service for all levels of society. Disabled community today can no longer be seen as 
society "second class" but they should be viewed the same and equal in every area of life.

\section{Conclusions}

Based on the results of the study, conclusions can be given as follows:

1. Services of Trans Metro Bandung have not fully provided accessibility facilities for persons with disabilities, both physical accessibility and information accessibility.

2. The unavailability of accessibility facilities for persons with disabilities in the Trans Metro Bandung service results in the emergence of difficulties experienced by persons with disabilities in using Trans Metro Bandung buses.

3. The results of this study provide the following recommendations:

4. Applying the principles of inclusiveness in the implementation of the Trans Metro Bandung service, which is open and accessible to all levels of society and puts forward the principle of equality in service delivery.

5. Accommodate the needs of persons with disabilities will be public transportation to the facilities complements the accessibility, both physical accessibility and the accessibility of information.

\section{References}

Adioetomo,. Et al. "Persons with Disabilities in Indonesia: Empirical Facts and Implications for Social Protection Policy". Via, $<$ http://www.asbindonesia.org/main/front/imag es/img media/Penyandang\%20Disability\%20di \%20Indonesia_Fakta\%20Empiris\%20untuk\%2 0Keb Policy\% 20Perlindungan\% 20Sosial\%20( Bahasa\% 20Indonesia) .pdf $>$ [25/10/17]

Ahmad, Mahtab. 2015. "Independent-Mobility Rights and the State of Public Transport Access for Disabled People: Evidence From Southern Punjab in Pakistan". Georgian Court University Journal of Administration \& Society No.2 Vol.47 2015.

Bezyak, Sabella. \& Gattis. 2017. "Public Transportation: An Investigation of Barriers for People with Disabilities". Journal of Disability Policy Studies 1 Vol. 282017.

Creswell, John. 2010. Research Design (Pendekatan Kualitatif, Kuantitatif, Mixed). Yogyakarta: Pustaka Pelajar.

Denhardt, Janet V \& Denhard, Robert B. 2007. The New Public Service: Serving, Not Steering. New York: M.E. Sharpe, Inc.

Dwiyanto, Agus. 2012. Manajemen Pelayanan Publik: Peduli, Inklusif dan Kolaboratif. Yogyakarta: UGM Press.

Electronic Reference:

Louca-Mai Wilson. "An Overview of the Literature on Disability and Transport". Via, $<$ https://disabilitystudies.leeds.ac.uk/wpcontent /uploads/sites/40/library/wilson-loucaDRCTransportLitreview.pdf $>[10 / 25 / 17]$

Miles, M.B \& M.A Huberman. 1992. Analisis Data Kualitatif. Jakarta: Penerbit Universitas Indonesia.

Rusli, Budiman. 2013. Kebijakan Publik Membangun Pelayanan Publik Yang Responsif. Bandung: Hakim Publishing

Soltani, Sham, Awang \& Yemen. 2012. "Accessibility for Disabled in Public Transportation Terminal". Procedia - Social and Behavioral Sciences No. 35. 